\title{
English as a Global Language in Chinese Context
}

\author{
Shengyong Zhang \\ Foreign Language Department of Dezhou University, Shandong, China \\ Email: jackyzhangshengyong@gmail.com
}

\begin{abstract}
In the forthcoming global environment, just as there seem to be two dominant economic global poles, China and the United States, so too it appears that two global languages, Chinese and English, will remain as the most dominant languages among the 6,912 languages in use. In this article, the author discusses why Chinese and English have taken on such significance globally, demonstrating their current and likely future impact linguistically, resulting in what might be called the G2 languages, Chinese and English. The author specifically discusses: Introduction of G2 languages: Chinese and English; The role of Chinese as a dominant world language; The role of English as a dominant world language; and Conclusion. References are included.
\end{abstract}

Index Terms - Chinese, English, G2 Languages, global languages

\section{INTRODUCTION OF G2 LANGUAGES: CHINESE AND ENGLISH}

In the global economic sphere, the largest global industrialized countries began as the G7: Canada, France, Germany, Italy, Japan, the United Kingdom and the United States. Later, G7 became the G8, adding Russia. In 2007, because of the emerging global financial and environmental crisis, a new G20 was created, adding such emerging countries as Brazil, China, India, and South Africa. Many writers suggest that while all of these units have their value, in the coming economic climate, there will only be a realistic G2: China and the United States, as the two most important global economic leaders. In the same way, we can see that dominant languages expand and contract in importance, and that currently there are two global languages that have a most significant world influence. These are Chinese and English. A discussion of these two languages forms the basic structure of this article.

Michael H. Prosser identifies the following aspects of language as verbal linguistic codes: verbal linguistic codes provide the link for cultural communication; speech is the basic coding procedure followed by language; language symbolizes and catalogs one's perceived reality; language universals or near universals serve as the primary link between language and cultures; language universals or near universals are summary statements about all human speakers; language universals or near universals may be distinguished by logical structure and substantive content; stability and change play a role in the understanding of grammatical systems, and the focus of language contact is the bilingual or polylingual individual. (1978, 1985, 1989, pp. 87-104, see also Donahue \& Prosser, 1997).

Prosser identifies such communication scholars as Richard Weaver, Marshall McLuhan, I.A. Richards, Kenneth Burke, Chaim Perelman, Michel Foucault, and Jurgen Habermas, although none were concerned primarily with sociolinguistics nor intercultural communication, as major contributors to the study of modern and contemporary language usage. For Weaver, all language is sermonic; for McLuhan, the essence of language, as it was for Aristotle, is the metaphor; for Richards, the goal of language is to bring understanding out of misunderstanding; for Burke, language and symbolic usage become the essence of communication to move humans toward cooperation and consubstantiality; for Perelman, he calls for the development of a universal audience through the appropriate use of language; for Foucault, he explores language, discourse and power; and for Habermas, he calls, as do Plato and Weaver, for language to lead men toward "the good life," while overcoming distorted language which leads to distorted cultural communication ( Donahue \& Prosser, 1997; Prosser, 2007, pp. 31-52).

There are 6,912 languages in use around the globe today (Gordon, 2005). Such a large number of languages make communication between people in different countries-or even in the same country in some cases-very difficult. Linguistics Professor David Crystal (2003, p. 9) provides two main elements in forming a global language: one is that a language that can be made the official language of a country to be used as a medium of communication in such domains as government, the law courts, the media, and the educational system; the other is that a language can be made a priority in a country's foreign-language teaching, even though this language has no official status. In reflecting on the above two elements, English has become undoubtedly a dominant international language. The demand for English language has increased exponentially with economic globalization. It is the language of air traffic control, international business and trade, diplomacy, technology, science, the internet, popular entertainment, international conferences, tourism, and even sports. For example, $80 \%$ of internet usage is in English. At the United Nations, where English and French are the two working languages, $80 \%$ of the delegates request their documents in English.

Approximately 375 million people speak English as their first language (Curtis, 2006). English today is probably the third largest language by number of native speakers, after Mandarin Chinese and Spanish (SIL Ethnologue, 2005, 2009). However, when combining native and non-native speakers, it is probably the most commonly spoken language in the world. Crystal calculates that non-native speakers now outnumber native speakers by a ratio of 3 to 1 (2003). 
Even in China, there are 350 million learners of English, more than the total populations of the United States, Canada, Australia, and New Zealand. But there is evidence that it is not the single global language. It has some rivals in at least some regions as the economies in those regions are growing in a fast pace, such as Spanish. Therefore, it is doubtful to claim that English will completely become a universal second language.

At first glance, Zhang believes that the most obvious option for the dominant global language would be Mandarin Chinese. It is spoken as a first language by over three times as many people as the English language (Gordon, 2005). Chinese is spoken by $1 / 5$ th of the population all over the world according to the findings made by available and reliable statistics. There is no field in which the Chinese people or people of Chinese origin have not made a name for themselves. Their sincerity and hardworking nature have gotten them genuine respect. China is visited by millions of tourists annually to see among other things The Forbidden City in Beijing and The Great Wall which is one of the Seven Wonders of the World, and it is no big surprise that it is becoming a famous destination for tourists and international businessmen and women equally. Many of them attend Chinese language and writing classes with the intention to speak and understand the Chinese language. Many websites and pod casts are now offering Chinese language lessons which can be learned for free. The global services delivery centers of many international corporations are being moved to China because of the necessity of Chinese language translation.

Meanwhile, according to the statistics of the China Scholarship Council in 2009, about 200 thousand international students from more than 180 countries are learning Chinese in China. For example, Beijing Language and Culture University has more than 7,000 foreign students learning Chinese and Chinese culture, the largest number of international students at one university in the world. Many universities in China have 1,000 to 3,000 foreign students in similar situations. In order to cater to the needs of learning Chinese around the world, 282 Confucius Institutes have been set up in more than 87 countries. Presently, more than 40 million people are learning Chinese and more than 2,500 universities from about 100 countries have set up Chinese language courses. More and more foreign countries have listed Chinese learning in their curriculum of primary schools, middle schools and secondary schools. In several countries of East Asia, Chinese has become a dominant regional language.

\section{The Role of Chinese as A Dominant World LANGUAGE}

At first glance, Zhang Shengyong believes that the role of Chinese today as a world language can be reflected clearly. As a result, learning Mandarin Chinese can often be an enjoyable and a very useful skill. With an economy growing by leaps and bounds, the importance of China on the world stage is increasingly felt. As noted in the introduction of this article, we are now faced with a situation in the not too distant future of a dominance of G2 languages. Chinese is the most frequently spoken language in the world with approximately 900 million speakers and is hence one of the key languages in the world culturally and in international business. Though some scholars would challenge this concept, Chinese and English can definitely be shown as the two most significant global languages now and in the foreseeable future. An important feature in contemporary China is that in the last two or so decades, 100 million illiterate Chinese have learned to read and write, due in part to the simplification of Chinese characters (China News, September 16, 2007. See also McBride-Chang \& Chen, 2003)

Table 1 below presents speaker estimates for the world's top 10 languages (given in millions), taken from Eric V. Gunnemark's Countries, People and Their Languages (a Geolinguistic Handbook).

TABLE 1:

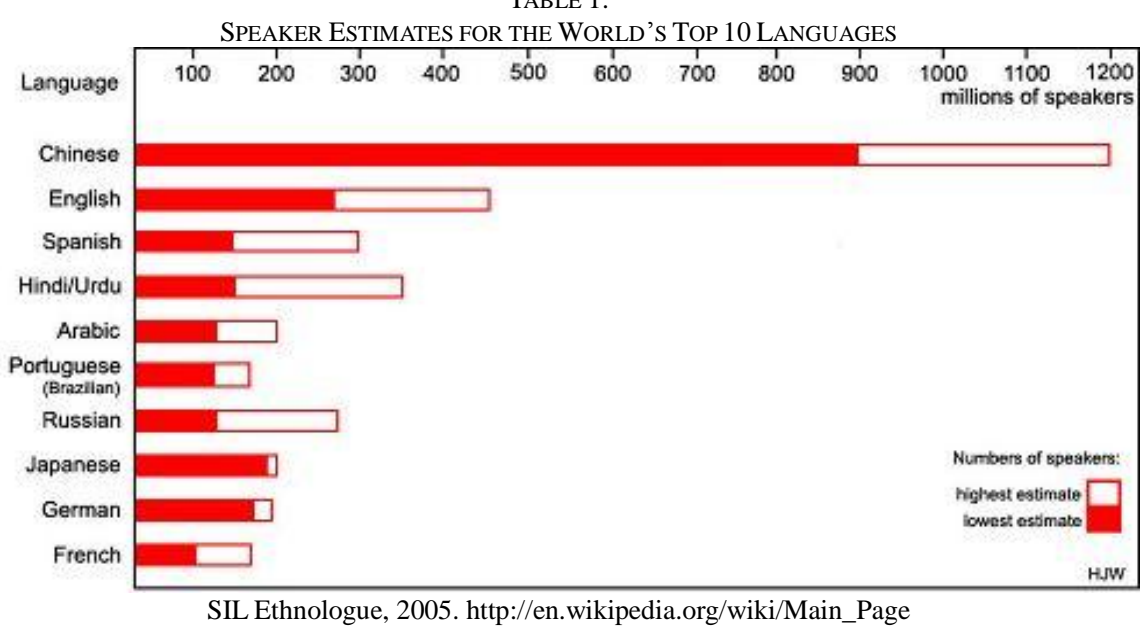


TABLE 2:

9 MAJOR WORLD LANGUAGES WITH THE ESTIMATED LARGEST NUMBERS OF SPEAKERS IN THE WORLD

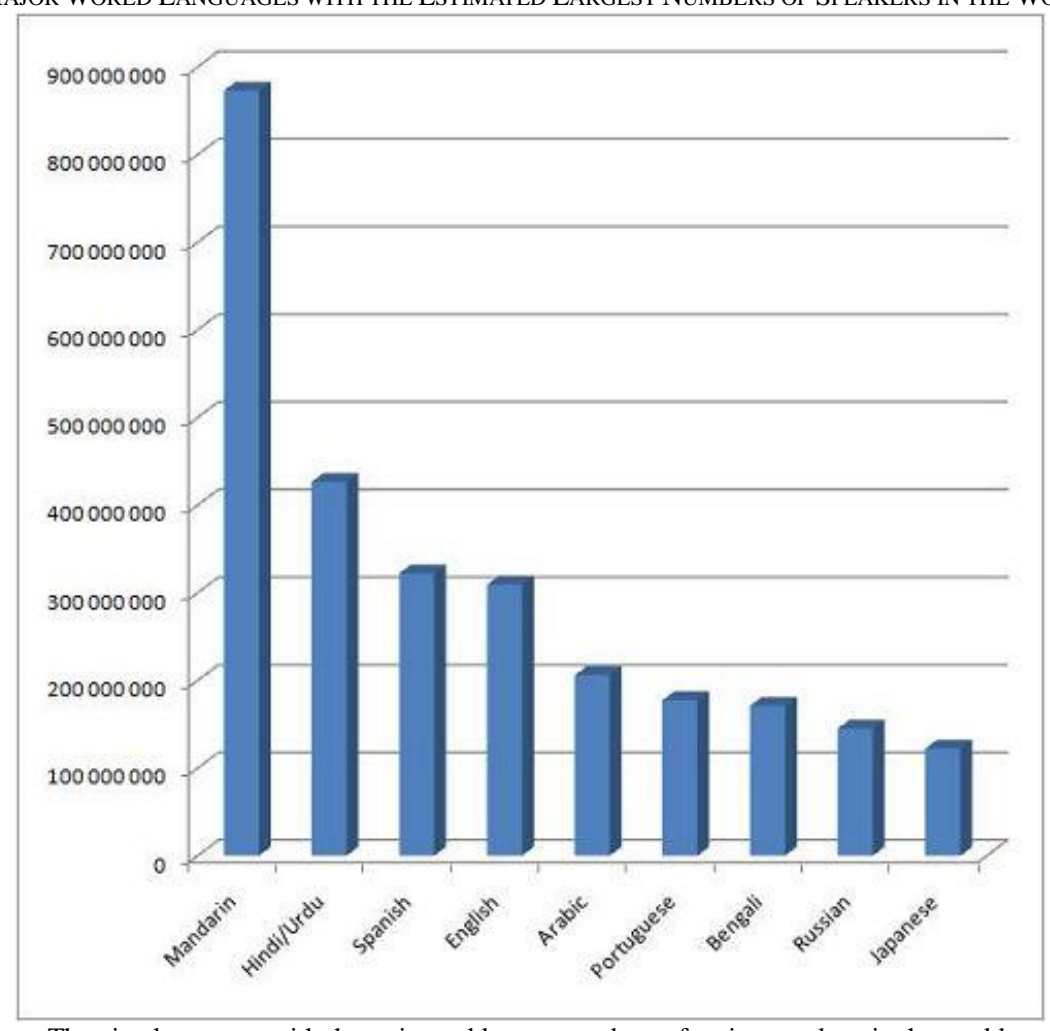

The nine languages with the estimated largest numbers of native speakers in the world, according to SIL Ethnologue, 2005. http://en.wikipedia.org/wiki/Main_Page

It is demonstrated by these tables that Chinese is doubly more dominant as a spoken native language than the next major language grouping, Hindu and Urdu. In this case, however, it is also notable that the second grouping comes from Asia too, and thus it is clear that Chinese, Hindu and Urdu, are all in a dominant global position. Following Crystal's view of how a global language might be developed, while Hindu and Urdu are both official languages in India, there are 15 official languages, including English. Generally, also, these languages are not spoken widely outside of Asia. In the case of Spanish, it is clearly a global language with native speakers in Spain and 20 South American and Caribbean countries as well as 30+\% in the United States and Canada, and also in this sense has more native speakers than in countries where English remains a national native language. The advantage of English as a dominant world language stems from its broad appeal not only as a national native language in major English speaking countries, but because it dominates so many fields of endeavor and frequently is considered the standard for multicultural settings.

\section{THE Global SPREAD OF CHINESE}

With China's long-term political stability and sustainable rapid economic development as well as the increasing exchanges in the areas of trade, culture and education between China and the international society, the demand for learning to speak Chinese is in dramatic growth in various countries across the world. Furthermore, the demand is expanding from academic and teaching areas to social folks and to foreign governments. According to Zhang Xinsheng, the Vice-Minister of Education and Managing Deputy Director of the State Leading Group for Teaching Chinese as a Foreign Language, the United States launched an AP Chinese task force by the end of 2003 and in American middle schools, students learn Chinese and in universities and colleges Chinese courses are counted as credits. According to preliminary investigations, 2,500 US primary and middle schools have offered Chinese course so far, whereas in the past there were only more than 200 schools. (see "World demand brings Chinese to the world," 2005) We have learned that there were only slightly more than 2,000 applicants taking the Chinese proficiency test or HSK (hanyu shuiping kaoshi in Chinese) more than 10 years ago. Currently, 34 countries in the world have set up 151 places of examination. In 2009, the number of the applicants reached 90,000 and the growth has been 40 per cent year on year in the past two or three years. There is a very popular demand for learning Chinese in countries of Southeast Asia, Europe, Africa and South America. The number of international students in China has nearly doubled from 110,844 in 2004 to 223,500 in 2008. The number of American students increased 2.35 times and European students 2.2 times. At the University of Hong Kong, more than half of the enrolled students are from overseas, with scholarships for all research postgraduate research students. The Hong Kong government invests an average of 510,000 Hong Kong dollars for the education of each student annually. More than $90 \%$ of the tuition is subsidized by the government and external funds (englisnews, 2010, 07, 10). 
For a number of years, China Central Television has placed high importance on bringing Chinese teaching programs overseas viewers; it has produced a series of Chinese teaching programs tailored for learners of different age groups and different needs. For overseas viewers, this is a convenient alternative to classroom learning of coming to China to study. In order to assist beginners to gain an innate understanding of dialogues in Chinese and quickly gain communication skills, China Central Television makes full use of the television medium to produce situational dialogues and provide pinyin, Chinese and English subtitles onscreen for the new vocabulary and common expressions, so that what viewers see, they can learn it cultivates a language environment and leaves a lasting impression.

According to the statistics of the China Scholarship Council in 2009, there are about 200 thousand foreign students from more than 180 countries of the world learning Chinese in China. And in order to satisfy with the needs of learning Chinese around the world, 282 Confucius Institute have set up in more than 87 countries. At present, more than 40 million people are learning Chinese and more than 2,500 universities from about 100 countries have set up the Chinese courses. More and more foreign countries have listed Chinese learning in the curriculum of primary junior and senior middle schools. In several countries of East Asia, Chinese has become the regional language.

China can open doors to employment in a variety of occupations such as in virtually any business related to manufacturing as well as in teaching, translation, interpreting, and the growing travel industry. In the United States or other Western countries with large Chinese communities, it can also lead to an increase rapport with Chinese employees that may be learning English or with contacts in companies abroad. With Asian economies growing significantly, learning Chinese greatly improves one's chances of success in job markets dealing with these economies. Studying Chinese can be a creative task, as well as an important one.

Although frequently and increasingly censored, the internet in China has played a considerable role in the development and usage of Chinese and English in China itself, and more broadly. During the late 1980s and 1990s, many Chinese postgraduate students were studying in the United States. Wei Wu discusses the development of the internet as a means for these students to keep in touch with each other in a rather strange intellectual environment. In March, 1989, two Chinese students in Canada proposed a plan for a communication network in North America. The small group quickly created an internet, China News Digest (CND) which quickly reached an early list of 400 readers. Later, several other Chinese networks emerged in the US and Canada, building their own North American cyber community (1998). In 2001, there were approximately 80 million internet users in China. At the end of 2009, there were 339 million internet users in China, with 42 million new users in the first half of the year. While English accounts for $80 \%$ of language use on the internet, $10 \%$ is accounted for by the Chinese language, and the other $10 \%$ represents all other languages used on the internet. The Chinese Baidu and American Google search engines have been in intense competition for several years. Baidu has consistently been well ahead of Google in Chinese market shares. Because of cyber attacks against Google in 2008 and 2009, Google is considering pulling out of China. This would be a serious loss for Chinese intellectuals and students.

However, we cannot ignore the other side of the Chinese popularity. When one wonders if Chinese will eventually overtake English as the global language, he or she has to realize that Chinese is already the most widely spoken language in the world, but that is because of the vast population of China. Outside the Chinese mainland, one wonders how many people have a basic or working knowledge of Chinese, either by choice or by compulsion? English on the other hand, is spoken by roughly 350 million people across the world and is gaining popularity in terms of usage and adaptability, even in China. It's a well-known fact that there is huge demand for English speaking professionals in China who can facilitate international business. There is also an acute demand for English teachers who can make the Chinese students better equipped for modern-day business and life. So from emerging trends, it seems evident that Chinese is not poised to overtake English as the most dominant global language, at least anytime soon. However, Chinese appears to be an equal partner with English as one of the two most significant languages globally. Admittedly, the Chinese economy is strong enough to boost the cause and popularity of its language, just as English did. But, it is possible that China's resurgent economy is a result of its ability to adapt to others' languages and way of work rather than the imposition of the Chinese language on other countries.

\section{The Role of English as a Dominant Global Language}

The author has already noted in Tables 1 the relationship of Chinese and English for the world's top 10 languages and 2, the relationship Chinese and English for the 9 major world languages with the estimated largest number of speakers in the world. Let us now consider the world speakers of English in a map of the world. 


\section{World speakers of English (blue)}

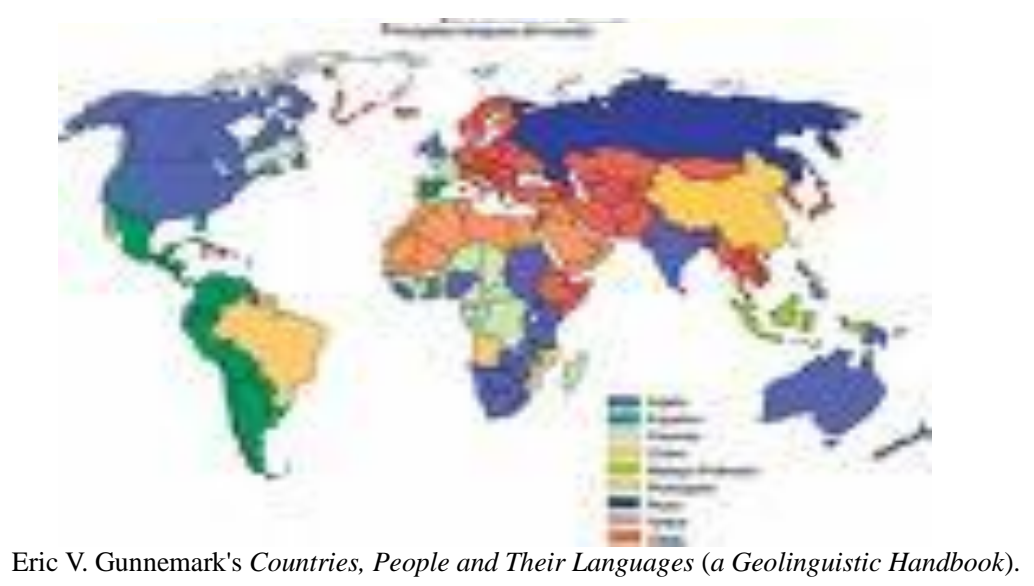

Aixa L. Rodriguez-Rodriguez stresses that industrialized nations, multinational corporations, and technological advancement all tend arrogantly to define globalization as universal, comprehensive, democratic, and all inclusive, but she believes that they actually mean these terms only in relation to their own interests, and not for less developed or emerging nations, traditional "have nots" such as women, minorities, and otherwise marginalized people. She argues that computer mediated communication through the internet cannot meet all of these definitions since English is the overwhelmingly dominant and therefore imperialistic language (1998).

The "China threat" concept probably would include both China and Chinese as a global language as a risk to the US and English and other dominant European global languages by such authors as Edward Timberlake and William C. Triplett II (1989); Richard Bernstein and Ross H. Munroe (1997), Bill Gertz “(2002); Herbert Yee and Ian Storey (2004) Dore Gold (2004), Hui Wang, Theodore Huters, and Rebecca E. Karl (2006), Minqi Li (2008), Martin Jacques (2009), Zachary Karabell (2009), Hui Wang (2010), and John Naisbitt and Doris Naisbitt (2010) and many others. Shengyong Zhang's MA thesis discusses the role of the United States Congressional Commission on Chinese security which issues an annual report identifying a genuine congressional concern about China's potential threat to the US (2009). In contrast, a frequent reader of China Daily and other government controlled newspapers in the mainland of China would recognize that many of the Chinese authors writing either as opinion columnists, or as news reporters, or even in the political cartoons on the editorial page have an anti US bias. Even prestigious academic Chinese scholars writing in the Journal of Middle Eastern and Islamic Studies (in Asia) for which Prosser is an editorial board member, worry consistently about the US as a long term threat to China. Although most of the books and articles may not explicitly tie the counter threat to the domination of one global language over the other, implicitly if one country is strongly criticized as arrogantly dominant over the other, then there is a threat also to the global language which each country represents as also hegemonic over the other.

Recognizing the problem of terms like "non-western cultures" as a potentially culturally imperialistic English usage on the part of Western academics, Prosser, when he was editor of Today's Speech: The Journal of the Eastern Speech Association Speech Association cited Theodore De Bary, then Professor of Chinese and Japanese Thought at Columbia University, saying that the designation of" non-western cultures" was as irrelevant and arrogant as saying that Jewish, Protestant, and oriental religions could be referred to as "non-Catholic." At the same time, many western universities and academic organizations were seriously promoting "non-Western culture" studies, for example, Harvard University, the East-West Center at the University of Hawaii, McGill University, UCLA, and the American universities in Iran, Turkey, Egypt, and Morocco, as well as The Middle East Studies Association, the Far Eastern Studies Association, the American Political Science Association, and the American Sociological Association. Therefore, Prosser, in his role as editor, for want of a better designation, centered one whole issue of Today's Speech on "non-western cultures" (1969).

So we can see that just as the notions of a "non-western" approach or of China threats to the US and US threats to China may be relative and negative semantic concepts, so too may be the idea that such European global languages as English, French, Portuguese and Spanish, because of an initial colonialistic heritage as imperialistic may be now also be an outdated concept. Whether these languages should have achieved global language status is now less the issue than the fact that these European languages have indeed achieved this role, and that English remains certainly the dominant language among these European languages.

Nobleza Asuncion-Lande directly confronts the issue of the English language as dominant and therefore imperialistic. She points out that linguistic usages can certainly denote and distinguish a dominant cultural pattern, for example, with English expressing individualism, competiveness, and democracy and Chinese and Southeastern Asian 
languages expressing collectivity, harmony and kinship: "A culture's linguistic system thus provides us with a sense of who its people are, and how and what they think." She continues: "Language can be viewed as a demarcation line between social classes. Many former colonies of Britain, France, Spain, Portugal and the United States have chosen to retain the languages of their colonizers as one of, or the official languages. These have also been adopted as the medium of communication among the elites, and confer to their speakers positions of status as well as mark them as educated and privileged" (1998, pp. 68-70).

Addressing the concept of the globalization of English, Asuncion-Lande says very strongly: "The emergence of English as the world's lingua franca is an unprecedented phenomenon in the history of linguistics.... English is ... the sole medium of communication of numerous international and regional organizations.... English is the dominant language of cyberspace... The dominance of English speaking media throughout the world is quite evident when one travels in non-English speaking countries.... The export of popular culture in English is growing at a fast pace.... In the realm of advertising, English appears to be the dominant language" (1998, pp. 72-74). She proposes that English, has in fact, become culture. Asuncion-Lande postulates that "live cultures are dynamic entities in contact with each other, exchanging, adopting, absorbing and discarding features that are found to be unproductive or irrelevant to new realities....[The] prospects for English as the dominant language of intercultural communication at least in the early part of the twenty-first century remains undiminished. English has developed its own momentum, aided by developments in information technology and growing interactions in world economy. No other language has achieved such a status or is likely to do so in the foreseeable future." (1998, pp. 79-80). She concludes: "The acceptance of its dominance by the world at large suggests the growth of a commonality, of values and norms between nations and cultures.... It [English] has become an international property that no one country can claim as its own" (pp. 75. 75, 79-80).

Power is of course a major component both in the internationalization and globalization of dominant languages, whether of a European origin, or in contrast, an Asian language such as Chinese throughout the world. This can have both positive and negative consequences. Just as Rodriguez-Rodriguez has noted, Asuncion-Lande agrees that the ability of English usage can be seen as pro-elite and anti-poor in nonnative English speaking countries throughout the world. Additionally, She points out that the emergence of "New Englishes" (for example, Philippine English, Indian English, Singapore English, or Nigerian English, to name a few) over time raises not only the question of whether there is a standard English on a world-wide basis. It is fair to say that on a spoken level, it is often difficult to understand different New Englishes, or sometimes even between people from the common native speakers of English from one country to the next, however, with some effort, such spoken English can be understood, and the written English can almost always be understood without great difficulty.

Many countries, often former British European (such as in Africa, or Asia or American colonies (such as the Philippines) which have long since adopted English as the official or preferred language (or French, Spanish, or Portuguese in their former colonies, for example), or have returned to English as the dominant language, have done so primarily to maintain an economic edge over other countries in the global marketplace. Asuncion-Lande notes Singapore, now one of the leading economic powers in Asia. Noting the argument against English as a neutral language in a world context, nevertheless, it is in fact a dominant global language, and in her perspective, it is THE dominant global language. In fact, Asuncion-Lande argues that not only is English THE dominant global language, but that American English is the world's lingua franca (pp.79).

The most recent SIL, Ethologue statistics indicate that there are a total of 478,367, 215 speakers of English, including native speakers, second and third English language speakers. This number is likely to be grossly underestimated as many citizens such as those in India or Nigeria with several official languages are likely to identify another language as their primary language. Among native speakers, the following represent the eight largest countries: 1.US: 280,000,000; 2. India: 100,000,000; 3. UK: 55,000,000; 4. Canada: 17, 100,000; 5. Australia: 15,682,000; 6. South Africa: 3,500,000; 7. New Zealand: 3, 203, 000; 8. Ireland: 2,600,000 (2009).

\section{ENGLish IN THE CHINESE CONTEXT}

While there many examples that can be offered about the spread of English, in this final section, we wish only to discuss it in the context of China which has been a very important development since the early 1970's, and increasingly so since the opening up of China in 1978 and 1985. While the newer American passports have requests for safe passage in English, French, and now also Spanish, the Chinese passport has the same request both in Chinese and English. Most major roads and express roads in China have signs with both Chinese and English information. Using pinyin, many stores now have signs both in Chinese and English.

As we have mentioned, there are 350 million learners of English in China, more than the total populations of the US, Canada, Australia, and New Zealand. The Ministry of Education reports that in 1999, there were 145 million pupils in Chinese primary schools and 91 million students in Chinese secondary schools and in 2002, there were 12 million college and university students. The United Nations Development Program indicated in 2003 that China had 116,390 kindergarten classes, with 613, 000 teachers and 20 million students; 425,846 million primary schools, with 5.7 million teachers, and 116, 8 million students, with a 51\% increase from 1998 to 2007. Most of China's better primary schools now begin teaching elementary English in the third grade. General secondary education included 79,490 schools, with 4.5 million teachers, and 85.8million students, plus 3, 065 special secondary schools, 199,000 teachers and 5 million 
students. If students did not begin learning English earlier, at least by the age of about twelve, they will have begun the process of learning English. In 2003, there were 1,552 institutions of higher education, with 725,000 teachers, and 11 million students. This number surpassed 2,236 institutions in 2007, with more than 18.9 million undergraduates, and 1.2 million postgraduate students. Because of China's emphasis on science and engineering, as the foundation in the early 1980's of the Four Modernizations and President Jiang Zemin's "3 Represents," each year 450,000 engineering students graduate from engineering programs ,50,000 with master's degrees, and 8,000 with Ph.D. degrees. All Chinese applicants for China's university admission or postgraduate programs must pass at least a written exam in English and in the college or university as undergraduates as sophomores they must pass English Band C 4, and many take English Band C 6 or other English certificate programs to enhance their opportunities for employment in international trade. Robin K. Cooper writes that in 2009 there were 671, 616 international students studying in the US, spending \$17 billion for tuition, travel, and living expenses, with 98,500 Chinese undergraduates studying in American universities (plus the postgraduates), a 21\% increase over 2008 (Facebox, Education in China, 2010, 01, 15, see also Internet Reuters, 2008, 12, 12; UN Human Development Report 2009).

Besides pupils and students enrolled in all levels of formal education, companies teaching English in China are among the most prosperous businesses. The New Oriental School (New Oriental Education and Technology Group), the largest private education company in China, founded by Michael Yu in 1993 is a primary example. Before the end of 2009, 7 million students were enrolled, including 1.5million in 2009, with 270 learning centers, including 48 schools, 23 New Oriental bookstores, plus 5,000 third party book stores, and approximately 5200 teachers in 40cities, and an online network of 5million registered users. Nearly 100,000 copies of New Oriental Magazine are sold monthly (www.NewOrientalSchool.com, 2010)

China's former Minister of Education, Zhou Li, has identified three major proposals for the reform in the teaching of English, noting that "The Ministry of Education and the universities have always attached great importance to the teaching of English to enable Chinese students to communicate in the language and develop a global vision." (Zhou, 2006, pp. 95-96). Thus, the Ministry has provided three major proposals:

First, the Ministry of Education has set new basic requirements for teaching English, with practicality and the students' comprehensive ability to use the language as the guideline. According to the new requirements, the teaching of English should shift its focus on reading to comprehension, and the traditional curriculum should be reformed to give universities autonomy and space for development.

The second proposal is to establish a campus-based English teaching network. The traditional reading mode of a blackboard, a piece of chalk and a textbook should be replaced by modern education technology to improve the students' self-learning ability.

The third proposal is to develop a new evaluation system to assess the teaching of English in colleges at different levels, from different angles, and during different processes. For example, evaluation should the students' learning process as well as their final examination. The teachers' work should be evaluated with reference to the students' progress. The Band Four and Band Six college English tests should also be further reformed to help students improve their ability to use the language. (Zhou, 2006, p. 96).

As we have noted, all college and university students in China must take and pass the CET-4 band test in English, usually in their second year of study. Many others take the CET-6 band test to provide themselves this credential for later study or employment, especially for international trade companies, most of which require a written test and often an oral test before candidates are chosen to work there. Among the large number of texts preparing students to take either the CET 4 or 6 exams, typically on a formulaic framework (title, topic sentence or paragraph, a main paragraph with pros and cons on the topic, a final summary paragraph, expressions of one's own views or most likely solutions to a stated problem), Zhou, Prosser, and Lu created a text with cross-cultural Chinese and American essays by Prosser and Lu, plus Chinese and American student writers, and cross-cultural analysis by Prosser (2003).

In addition to the reforms in moving English from a reading language to a comprehensively understood and spoken language, Ji also noted the Chinese Ministry of Education's 2001 reforms in bilingual education among China's colleges and universities which was intended to teach a number of subjects to actively promote the use of English and some other foreign languages in the teaching of such fields of study as biotechnology, information technology, law, and finance and other specialty courses for undergraduates. In 2001, China began to send faculty of basic subjects to English native language countries to improve their English and subject-based training. By 2004, university and other presses had greatly expanded their English language text books, with more than 1400 computer science texts alone (Ji, 2006, pp. 96).

Jia and Jia stress that it is not enough simply to say that Chinese are learning English, but that the symbols which are a part of the social processes have meaning only in the context of cultural and social settings, thus requiring an understanding the social, cultural, political and ethnic boundaries through the communicative processes that inform them: "The situation at present is that Anglo-American English has been considered as Standard English...and as a lingua franca in the Chinese cultural context...This variety of English used by the Chinese is generally called China English, which develops from both internationalization and indigenization of Anglo-American English. It has the native-speaker based world of English as its core system but integrates with Chinese symbolic systems, underpinned with Chinese cultural values." They argue that "English is used for every aspect of life in China. This is of great 
significance for both China and the international community, because China and the world need to enter one another's world in their pursuit of peace and further development. Without China-English, communication between China and the world is almost impossible today" (2007).

\section{CONCLUSION}

Many inventions which were expected to be the signs of the future in 2000 have now been seen as obsolete. ImpactLab has proposed that momentous global changes can also be expected in the second decade of the twenty-first century. Cautiously predictive, it has been argued that the dominant characteristics in 2020 could well be: "four key aspects of second decade can be discerned. The rise of China; the (relative) decline of the US; the expanding role of the global south; and finally, possibly most dramatically, the increasing impact of a roiling environment and growing resource scarcity" $(2010,01,12)$.

Certainly in terms of the first prediction, we can argue that while the nineteenth century might have been called the British century, because of the industrial revolution; the twentieth century could have been called the American century, because of its increasing superpower, and perhaps even hyperpower status after the end of WWII; then the twenty-first century might realistically be called the Asian century, given the rising economic status of both China and India, representing a population of more than one fourth of the world's total number of people. A number of writers have also suggested that in fact the current century might be called the China century, because of its increasing dominance internationally and globally in many of its endeavors.

Understanding, that the second prediction notes that the US will be relatively weaker by 2020 , this depends upon a great extent whether the United States can help to solve the major global and regional issues through unified efforts with other leading international stakeholders. Additionally, in the event that Barack Obama succeeds in leading the US out of recession, can help solve the many domestic issues facing the American people and can work effectively with other world leaders, determines if former Secretary of State Colin Powell's statement in the last week of the 2008 election that Obama is "a culturally transformational figure" actually develops over time. Prosser, following Powell's statement, has recently argued that Obama has exhibited culturally transformational identities and accommodations in his approach to the Middle East and Islam (2009).

When Obama received the 2009 Nobel Prize for Peace, the Oslo committee determined that it was in anticipation that he could help to bring about a world of greater peace, especially in the Middle East. The third prediction of the expansion of the role of the global south seems very realistic, noting the growth of various regional international organizations, and seeing the development of a G20, incorporating such emerging powers as Brazil, China, India, and South Africa, in its efforts to solve the world economic crisis beginning in 2008, or earlier. Finally, the last prediction, about the roiling environment and growing resource scarcity, seems highly reliable, as has been noted in the December, 2009 Copenhagen UN conference on climate change, which unfortunately was unsuccessful, but has the possibility of at least a start in international negotiations toward productive solutions to the enveloping crisis. It is also clear that resource scarcity is a growing threat in many areas such as sustainable development, food and water resources, and other energy sources.

Finally, the author notes the ideas expressed in their joint article in The Wall Street Journal, by US Secretary of State Hilary Clinton and US Secretary of Treasury Timothy Geithner. Initially, calling for "A new strategic and economic dialogue China," they indicate that "Today's China's GDP tops four trillion dollars, thousands of emails and cellphone calls cross the Pacific Ocean daily, and by next year [2010] there will be 249 direct flights per week between the U.S. and China." They continue: "In April [2009], President Barack Obama and President Hu Jintao announced new dialogue as part of the administration's efforts to build a positive, cooperative and comprehensive relationship with Beijing." Stressing their major point, Clinton and Geithner, recognizing that three main points for dialogue include recovery from the global economic crisis; the interconnected issues of climate change, energy, and the environment; and finding complementary approaches to security and development challenges in the region and across the globe, argue: "Simply put, few global problems can be solved by the U.S. or China alone. And few can be solved without the U.S. and China together. The strength of the global economy, the health of the global environment, the stability of fragile states and the solution to nonproliferation challenges turn in large measure on cooperation between the U.S. and China." Concluding their article, they state: "The Chinese have a wise aphorism, 'When you are in a common boat you need to cross the river peacefully together.' Today, we will join our Chinese counterparts in grabbing an oar and starting to row" $(2009,07,27)$.

Clinton and Geithner's article suggests why we have chosen to discuss the G2 languages: Chinese and English in this article as a significant aspect of the growing importance of China and the US, moving beyond their influence globally to what may be the most likely situation in the next decade: China and the US, and Chinese and the English as the two most global languages.

\section{REFERENCES}

[1] Aczel, A. (2002). The riddle of the compass: The invention that changed the world. San Diego: Harcourt.

[2] Adshed, S.A. M. (2000). China in world history, third edition. London: MacMillan Press Ltd.

[3] Asian universities become big draw for foreign students. (2010, 07,10). englisnews@ chosum.com/Jan.13.2010,07.10KST 
[4] Asuncion-Lande, N. (1998). English as the dominant language for intercultural communication: Prospects for the next century. In K.S. Sitaram \& M.H. Prosser, Eds. (1998). P 67-82, Civic discourse: Multiculturalism, cultural diversity and global communication. Stamford, CT: Ablex Publishing Corp.

[5] Bate, W. J. (1995). The achievements of Samuel Johnson. Oxford: Oxford University Press.

[6] Bernstein, R. \& Munro, R. H. (1997). The coming conflict with China. New York: Knopf.

[7] Boswell, J. (1986). The life of Samuel Johnson. C. Hibbert, Ed. New York: Penguin Classics.

[8] China news. Retrieved on 16 September 2007 from www.xinhua.net

[9] Chinese government scholarship program. Retrieved on $1^{\text {st }}$ December 2009 from http://en.csc.edu.cn/Laihua/?cid=476

[10] Clinton, H. R. \& Geithner, T. (2009, 07, 27). A new strategic and economic dialogue with China. The Wall Street Journal.

[11] Cooper, R. (2010, 01,15). The Business Review: Int'l students flock to US schools. Institute of International Education.

[12] Crystal, D. (1988). The English language. Harmondsworth, England: Penguin Classics.

[13] Crystal, D. (2003). English as a global language (2nd ed.). London: Cambridge University Press, p. 69.

[14] Curtis, A. (2006). Color, race, and English language teaching: shades of meaning. Hillsdale, NJ: Lawrence Erlbaum Assoc Inc., p192.

[15] Davis, L. (1999). Doing culture. Beijing: Foreign Language, Teaching and Research Press.

[16] Deng, Y. (2005). Ancient Chinese inventions. Trans. By W. Pengxing. Beijing: Intercontinental Press.

[17] Donahue \&Prosser. (1997). Diplomatic discourse: International conflict at the United Nations. Greenwich, CT: Ablex.

[18] Ellis, J. J. (1979). After the revolution: Profiles of early American culture. Queensland: University of Queensland Press.

[19] Facebox. (2010, 01, 15). Education in China. Facebox.

[20] Gertz, B. (2002). The China threat: How the People's Republic targets America. Washington, DC: Regnery Publishing Company.

[21] Gordon, R. G., Jr. (Ed.) (2005). Ethnologue: languages of the world, 15th Edition. SIL International, Dallas, TX. Retrieved 23 Jan. 2006, from www.ethnologue.com.

[22] Government of the City of Taipei. (2002). Advantages and disadvantages on traditional characters vs. simplified characters (in Chinese). Taipei, Taiwan: Government of the City of Taipei.

[23] Gunnemark, E.V. (1991).Countries, People and Their Languages (A Geolinguistic Handbook), Gothenburg, Sweden: Social Sciences Resource Center.

[24] Hale, C. \& Scanton, J. (1999). Wired styles: Principles of English usage in the digital age. New York: Broadway Books.

[25] Impact Lab. (2010, 01, 12). Momentous shifts in global power by2020. Impact Lab.

[26] International Institute of Education. (2010, 01,15). The business review: Int'l students flock to US. International Institute of Education.

[27] Internet Reuters. $(2008,12,12)$. China economy at crossroads after 30 years of reform. Internet Reuters. Retrieved 2009, 06, 15.

[28] Jia, Y. X. \& Jia, X. R. (2007). The study of Chinese language behavior cross-culturally: A sociolinguistic approach to intercultural communication. In S.J. Kulich \& M. H. Prosser (Eds.)(p129-174). Intercultural perspectives on Chinese communication. Shanghai: Shanghai Foreign Language Education Press.

[29] Johnson, S. (1755). Dictionary of the English language. Facsimile edition, CD-ROM. Ed. A. McDermott.

[30] Karabell, Z. (2009). Superfusion: How China and America become one economy and why the world's prosperity depends on it. New York: Simon and Schuster.

[31] Lewis, M. P. (Ed). (2009). Languages of the world. The World Almanac and Book of Facts 2009 and Ethnologue: Languages of the World, 16th ed. 0L: www.ethnologue.com/web.asp.

[32] Li, M. (2008). The rise of China and the demise of the capitalist world economy. London: Pluto Press.

[33] Martin, J. (2009). When China rules the world: The end of the western world and the birth of a new global world order. London: Allen Lane.

[34] McBride-Chang, C. \& Chen, H-C. (2003). Reading developments in Chinese children. Westport, CT: Praeger/Greenwood.

[35] McCrum, R., Cran, W. \& MacNeil, R. (1986). The story of English. New York: Viking.

[36] McDonald, J. (2010, 01, 10). China becomes biggest exporter, edging out Germany. Associated Press.

[37] Mencken, H.L. (1963). The American language: An inquiry into the development of English in the United States. R. I. McDavid, Ed. New York: Alfred A. Knopf.

[38] Mickethwait, D. (2005). Noah Webster and the American Dictionary. New York: McFarland.

[39] Naisbitt, J. \& Naisbitt, D. (2010). China's megatrends: The 8 pillars of a new society. New York: Harper Collins.

[40] New World Encyclopedia. (Jan. 23, 2009). Simplified Chinese character. New World Encyclopedia. New York: New World Encyclopedia. Retrieved Jan. 23,2010.

[41] 100 Min illiterates learned to read and write in decade. (July 29, 2007). China News. Retrieved September 16, 2008.

[42] Oxford University Press. (1999). Oxford American dictionary and language guide. New York: Oxford University Press.

[43] Peoples' Daily Online. (2006, 10, 31). US universities favor Chinese graduate students. Peoples' Daily Online.

[44] Prosser, M.H. (1969). Column one: Communication and non-western cultures. Today's speech: The Journal of the Speech Communication Association of the Eastern States, 17. 1.

[45] Prosser, M. H. (2007). One world, one dream: Harmonizing society through intercultural communication: A prelude to China intercultural communication studies. In S.J. Kulich \& M. H. Prosser (Eds.) (2007). Intercultural perspectives on Chinese communication. Shanghai: Shanghai Foreign Language Education Press.

[46] Prosser, M.H. (2009: September). Obama's culturally transformational identities and accommodations toward the Middle East and Islam. Journal of Middle Eastern and Islamic Studies (in Asia) 3. 3.

[47] Rodriguez-Rodriguez, A. L. (1998). How global is global? A critical look at the language and ideology of globalization. In K.S. Sitaram \& M.H. Prosser, Eds. (p83-94). Civic discourse: Multiculturalism, cultural diversity and global communication. Stamford, CT: Ablex Publishing Corp.

[48] SIL Ethnologue. (2005, 2009). http://en.wikipedia.org/wiki/Main_Page. 
[49] Sivin, N. (1995). Science in ancient China: Researches and reflections. Brookfield, VT: VARIORUM. Ashgate Publishing.

[50] Strunk, W, Jr. \& White, E.B. (1979). The elements of style, $3^{\text {rd }}$ edition. New York: Macmillan.

[51] Timberlake, E. \& Triplett, II, W.C. (1989). Red dragon rising: Communist China's military threat to America. Washington, DC: Regnery.

[52] UN development report. (2008). New York: United Nations.

[53] Unger, H.G. (1998). Noah Webster: The life and times of an American patriot. New York: John Wiley and Sons.

[54] USA Today. (2009, 12,8). Chinese college students flocking to U.S. campuses. USA Today.

[55] Wang, H. (2010). The end of the revolution: China and the limits of modernity. London: Verso.

[56] Wang, H., Huters, T., \& Karl, R.E. (2006). China's new order: Society, politics, and economy in transition. Cambridge, MA: Harvard University Press.

[57] Webster, N. (1828). An American dictionary of the English language. Facsimile Edition, CD-ROM.

[58] World demand brings Chinese language to the world. (n.d.). Retrieved June,16, 2005 from http://english.peopledaily.com.cn/200506/16/eng20050616_190664.html.

[59] Wu, W. (1999). Cyberspace and cultural identity - A case study of cybercommunity of Chinese students in the United States. In M.H. Prosser \& K.S. Sitaram, Eds. Civic Discourse: Intercultural, International and Global Media. Stamford, CT: Ablex.

[60] Yee, H. \& Storey, I. (2004). China threat: Perceptions, myths, and reality. New York: RoutledgeCurzon.

[61] Zhou, J. (2006). Higher education in China. Singapore: Thompson.

[62] Zhou, L., Prosser, M. H. \& Lu, J. (Eds.) (2003). Sino-American compositions of shared topics. Zhengzhou: Henan Peoples' Press.

Shengyong Zhang now works in Foreign Language Department of Dezhou University. He got M.A. degree majoring in International Relations from Shanghai International Studies University in 2009. From 2008 till now, Zhang has attended several international conferences both at home and abroad. In 2009, he attended the $15^{\text {th }}$ International Association for Intercultural Communication Studies World Conference in Japan; and he attended the $8^{\text {th }}$ CAFIC International Conference in Beijing China; In November 2009, he was invited to University of Bangkok Thailand to have a short visit. Then from June 2010, he went to several universities in Singapore (attending the 2010 International Conference of International Communication Association), Malaysia and Indonesia. As an English teacher in the Foreign Language Department of Dezhou University, Zhang has consistently enriched his English language skills by many contacts with a wide range of America. He studied in University of Virginia of United States from July to November 2010. 